\title{
Editorial:
}

\section{Chikungunya virus outbreak-a threat to global public health including Bangladesh}

\author{
Mahdy $A A^{1}$, Jamal $M^{2}$, Kinoshita $H^{3}$, Hossan $T^{4}$
}

Bangladesh Journal of Medical Science Vol. 17 No. 02 April'18. Page :183-184

DOI: http://dx.doi.org/10.3329/bjms.v17i2.35868

\section{Introduction}

Chikungunya (CHIK) is a mosquito-borne disease causes by the CHIK virus. It was first identified during an outbreak in southern Tanzania in 1952. Following that, the virus was found in some other parts of Africa and has spread to Southeast Asian countries that include India, Pakistan, Thailand, China, and the Philippines etc ${ }^{1}$. In 2008, a CHIK outbreak was reported for the first time in rural Bangladesh $^{2}$. Recently, CHIK has been found in the city of Dhaka, the capital of Bangladesh ${ }^{3}$ which hit nearly every family in the city. Surprisingly, most of the cases remained undiagnosed due to the lack of awareness and diagnostic facilities. Today, the virus continues to place a significant burden on the global healthcare systems, particularly in Bangladesh. Nonetheless, CHIK has received little attention in the medical community, unlike other arboviruses such as Dengue or Zika, owing to its self-limiting nature with rare severe complications.

\section{Chikungunya virus}

CHIK virus is one of the members of the alphavirus genus in the family Togavirida which is made up of a single strand of RNA. The RNA synthesis presumably occurs on the cytoplasmic side of the plasma membrane and/or modified endosomal membranes ${ }^{4,5}$. The RNA encodes four nonstructural proteins involved in virus replication and pathogenesis, and five structural proteins that compose the virion. There are severel strains of CHIK virus, which differ from one another in their RNA sequences. These different strains are grouped into three genotypes: West African, Asian and East/Central/South African (ECSA). The latter two genotypes have caused global outbreaks in recent years. CHIK viruses have antigenic profiles that make them unique among viruses, including other alphaviruses. Antigens serve to promote viral infectiousness and to stimulate antibody production by the host's immune system. The antibodies (IgG, IgM) against the CHIK virus enables the virus to be detected by serological tests.

\section{Chikungunya infection}

The virus is primarily transmitted to humans through the bite of an infected mosquito from the Aedes genus, mainly Aedis Aegypti and Aedis Albopictus. It replicates in the skin fibroblast and then disseminates to several regions of the body such as liver, joints, muscles, lymphoid tissue and brain, presumably through the blood ${ }^{6}$. Mother to fetus transmission has also been reported with some adverse outcomes in babies? ${ }^{7}$. Once the virus is introduced into the blood stream, symptoms start showing such as high fever with shaking chills and moderate to severe joint pain that may persist for months to years even after recovery from the acute illness ${ }^{8}$. Other symptoms may include headache, myalgia, arthritis, conjunctivitis, nausea, vomiting, or a maculopapular rash. Rarely, encephalitis and other neurological involvements may also complicate CHIK viral infection ${ }^{9}$. Although, CHIK is not a fatal disease, the virus can contribute to the cause of death in neonate, young children or the elderly ${ }^{10}$.

1. Abdullah Al Mahdy, 2nd year undergraduate students, Department of Biochemistry and Molecular Biology, Jahangirnagar University, Dhaka-1342, Bangladesh

2. Mostofa Jamal, Assistant Professor, Department of Forensic Medicine, Faculty of Medicine, Kagawa University, 1750-1, Ikenobe, Miki, Kita, Kagawa 761-0793, Japan,

3. Hiroshi Kinoshita, Professor and head, Department of Forensic Medicine, Faculty of Medicine, Kagawa University, 1750-1, Ikenobe, Miki, Kita, Kagawa 761-0793, Japan

4. Tareq Hossan, Lecturer, Department of Biochemistry and Molecular Biology, Jahangirnagar University, Dhaka-1342 Bangladesh

Correspondence to: Mostofa Jamal, Assistant Professor, Department of Forensic Medicine. Faculty of Medicine, Kagawa University, 1750-1, Ikenobe, Miki, Kita, Kagawa 761-0793, Japan,

E-mail: jamal@med.kagawa-u.ac.jp 


\section{Laboratory diagnosis and treatment}

A diagnosis can be made by testing serum or plasma to detect the virus, viral nucleic acid, or virus-specific antibodies (IgM and $\operatorname{IgG}$ ). Given the fact that there is currently no specific antiviral agent to treat CHIK infections and no approved vaccine, research in these fields has been increasing. Treatment is symptomatic and supportive, and can include good hydration, the use of non-anti-inflammatory antipyretic (acetaminophen) and anti-histamines for pruritus control. Rest can provide relief for some of the symptoms. The only practical options are vector control and source reduction. Public awareness and health education about CHIK fever will also help to control the problem better.

\section{$\underline{\text { References }}$}

1. Wahid B, Ali A, Rafique S, Idrees M. Global expansion of chikungunya virus: mapping the 64-year history. Int $J$ Infect Dis. 2017; 58:69-76.

2. Selina Khatun, Apurba Chakraborty, Mahmudur Rahman, Nuzhat Nasreen Banu, Mohammad Mostafizur Rahman, S. M. Murshid Hasan, Stephen P. Luby, and Emily S. Gurley. An Outbreak of Chikungunya in Rural Bangladesh, 2011. PLoS Negl Trop Dis. 2015; 9: e0003907.

3. Hassan R, Rahman MM, Moniruzzaman M, Rahim A, Barua S, Biswas R, Biswas P, Mowla SG, Chowdhury MJ. Chikungunya -an emerging infection in Bangladesh: a case series. J Med Case Rep. 2014; 8:67.

4. Froshauer_S, Kartenbeck J, Helenius A. Alphavirus RNA replicase is located on the cytoplasmic surface of endosomes and lysosomes. J Cell Biol. 1988; 107:207586.

5. Frolova EI, Gorchakov R, Pereboeva L, Atasheva S, Frolov I. Functional Sindbis virus replicative complexes are formed at the plasma membrane. J Virol. 2010; 84:11679-95.

6. Schwartz O, Albert ML.Biology and pathogenesis of chikungunya virus. Nat Rev Microbiol. 2010; 8:491-500.

7. Ramful D, Carbonnier M, Pasquet M, Bouhmani B, Ghazouani J, Noormahomed T, Beullier G, Attali T, Samperiz S, Fourmaintraux A, Alessandri JL.. Motherto-child transmission of Chikungunya virus infection. Pediatr Infect Dis J. 2007; 26:811-5.

8. Poo YS, Rudd PA, Gardner J. Multiple immune factors are involved in controlling acute and chronic Chikungunya virus infection. PLoS Negl Trop Dis. 2014; 8:e3354.

9. Bandeira AC, Campos GS, Sardi I. Neonatal encephalitis due to Chikungunya vertical transmission: first report in Brazil. ID Cases. 2016; 5:57-59.

10. Mavalankar D, Shastri P, Bandyopadhyay T, Parmar J, Ramani KV. Increased mortality rate associated with chikungunya epidemic, Ahmedabad, India. Emerg Infect Dis. 2008; 14:412-5. 